INSTITUTE OF FORESTRY • BELGRADE

INSTITUT ZA ŠUMARSTVO • BEOGRAD

SUSTAINABLE FORESTRY

COLLECTION 77-78, 2018

ODRŽIVO ŠUMARSTVO

ZBORNIK RADOVA 77-78, 2018

UDK 551.3.053:630*384(497.11-12)

UDK 630*116.6:630*384.2/.3(497.11-12)

Original scientific paper

\title{
EFFECTS OF EROSION CONTROL WORKS IN THE DRAINAGE BASIN OF THE PALOJSKA RIVER (GRDELICA GORGE)
}

\author{
Sonja BRAUNOVIĆ ${ }^{\prime}$, Filip JOVANOVIĆ ${ }^{2}$, Milan KABILJO ${ }^{l}$, \\ Natalija MOMIROVIĆl
}

\begin{abstract}
The paper examines the effects of erosion control works performed in the Palojska River Basin, based on a comparative analysis of erosion intensities in 1953 and 2016. Intensive processes of erosion in the basin were reduced by performing technical works in the channel and biological and technical works on the slopes. The effects of the works conducted, accompanied by changes in the land use and socio-demography, are manifested in the reduction of the erosion coefficient from $Z=1.02$ (surface excessive erosion) in 1953 to $Z=0.28$ (mixed weak erosion) in 2016 and in the reduction of the sediment yield and transport in the basin.
\end{abstract}

Keywords: erosion process intensity, erosion control works, Palojska River, Grdelica Gorge, Serbia

\footnotetext{
${ }^{1}$ Dr Sonja Braunović, MSc Milan Kabiljo, MScNatalija Momirović, Institute of Forestry, 3 Kneza Višeslava, 11030 Belgrade, Serbia.

${ }^{2}$ BSc Filip Jovanović, Faculty of Forestry, University of Belgrade, 1 Kneza Višeslava, 11030 Belgrade, Serbia.

Corresponding author: Sonja Braunović, Institute of Forestry, 3 Kneza Višeslava, 11030 Belgrade, Serbia, +381628838014, e-mail: sonja.braunovic@ @ forest.org.rs

* Acknowledgements: The research was realized within the project 'The development of technological procedures in forestry with a view to an optimum forest cover realization" (TR31070), 2011-2018, financed by the Ministry of Science and Technological Development of the Republic of Serbia.
} 


\section{EFEKTI PROTIVEROZIONIH RADOVA U SLIVU PALOJSKE REKE (GRDELIČKA KLISURA)}

Izvod: $U$ radu su sagledani efekti izvedenih protiverozionih radova u slivu Palojske reke, na osnovu uporedne analize intenziteta erozije u 1953. i 2016. godini. Intenzivni procesi erozije $u$ slivu sanirani su izvođenjem tehnickih radova $u$ koritu $i$ bioloških $i$ tehničkih radova na padinama. Uspeh izvedenih radova, uz promenu načina korišćenja zemljišta $i$ sociodemografske promene, izražen je kroz smanjenje vrednosti koeficijenta erozije sa $Z=1,02$ (površinska ekscesivna erozija) u 1953. godini, na $Z=0,28$ (mešovita slaba erozija) u 2016. godini i smanjenje produkcije i pronosa nanosa u slivu.

Ključne reči: intenzitet erozionih procesa, protiverozioni radovi, Palojska reka, Grdelička klisura, Srbija

\section{INTRODUCTION}

It is a worrying fact that $40 \%$ of the territory of Serbia is currently affected by erosion processes of excessive, severe and moderate intensity. There are over 12,000 torrents that endanger the economy, infrastructure, and often human lives. The damage incurred can be viewed from several different aspects - soil erosion and sediment deposition in accumulations and regulated watercourses (water management aspect); reduction of soil fertility and sediment deposition in arable land (agricultural aspect); damage to roads, industrial buildings, human settlements, etc. (economic aspect), chemical and mechanical pollution of watercourses and reservoirs (ecological aspect) (Braunović, 2013; Braunović and Perović, 2017).

The first erosion control works in Serbia are related to those made at the beginning of the $20^{\text {th }}$ century in Grdelica Gorge. A total of 58 basins of Grdelica Gorge were protected against excessive erosion in the period between 1947 and 1977 (Kostadinov et al., 2008; Braunović et al., 2017). Since then, the scope of erosion control works in Serbia had been decreasing so that at the beginning of the $21^{\text {st }}$ century these works were reduced to the rehabilitation of existing structures.

\section{MATERIAL AND METHODS}

\subsection{Research Area}

The Palojska River Basin is located in eastern Serbia (northeastern part of Grdelica Gorge) (Picture 1). 


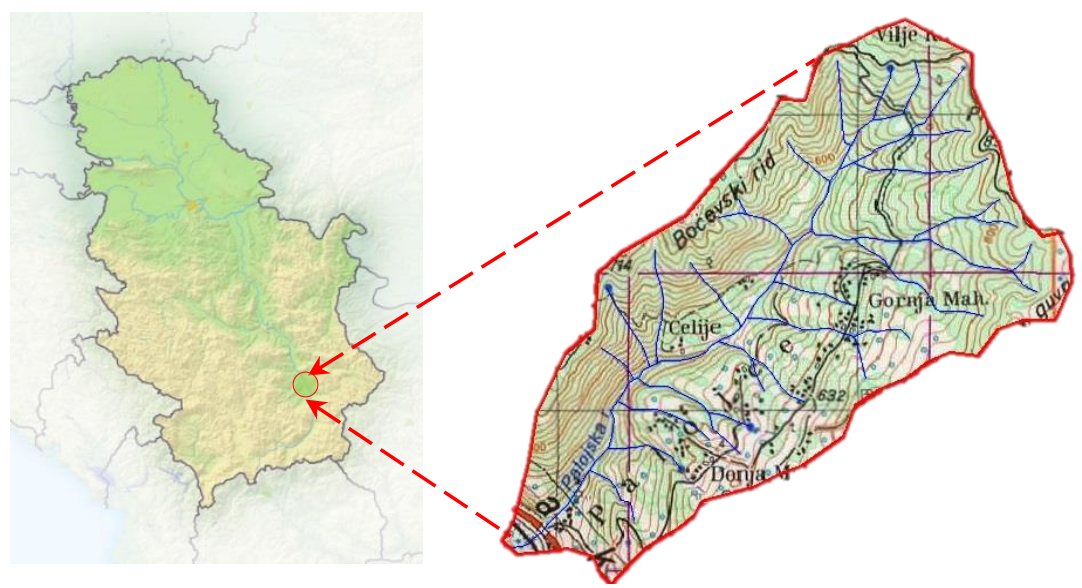

Picture 1. The geographical position of the Palojska River Basin

The Palojska River is a right tributary of the South Morava River and it flows through the municipality of Leskovac, i.e., cadastral municipalities Palojce (91.7\% of the basin area) and parts of cadastral municipalities of Dedina bara, Boćevica, Novo Selo, Bojišina and Vilje Kolo.

The basin is elongated, stretching on an area of $6.87 \mathrm{~km}^{2}$ in the northeastern-southwestern direction. The mean width of the basin is $1.5 \mathrm{~km}$. The main stream is $4.6 \mathrm{~km}$ long, with the mean drop of $16 \%$ (6\% in the lower course, $16 \%$ in the middle course and $27 \%$ in the upper course). The average slope in the basin is $35 \%$, with significantly larger drops and a large number of gullies on the right side of the basin. The source is at $700 \mathrm{~m}$ above sea level, and its mouth is at $265 \mathrm{~m}$ above sea level, which points to the pronounced energy of relief. The largest portion of the Palojska River Basin (76.27\%) lies in the altitudinal zone from 500 $\mathrm{m}$ to $1000 \mathrm{~m}$, and $23.73 \%$ of the total surface area of the basin is in the zone from $265 \mathrm{~m}$ to $500 \mathrm{~m}$ (Picture 2). The slope ranges from $1 \%$ to $55 \%$. The dominant slopes range from $20 \%$ to $30 \%$ and they account for $35.64 \%$ of the surface area of the basin. The slopes ranging from $15 \%$ to $20 \%$ account for $31.50 \%$ of the total area, and the slopes of $30-55 \%$ for $8.62 \%$ (Picture 3).

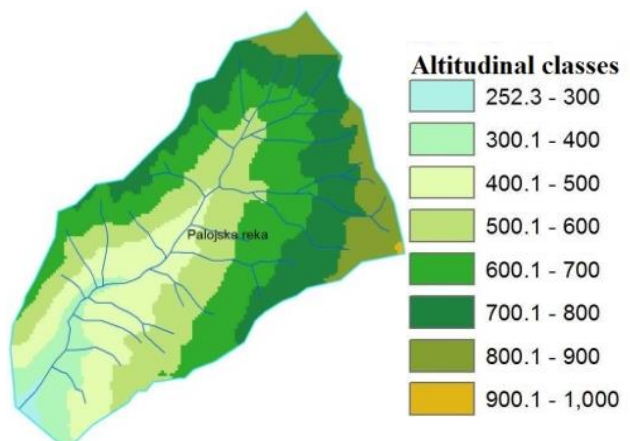

Picture 2. Altitudinal zones in the basin

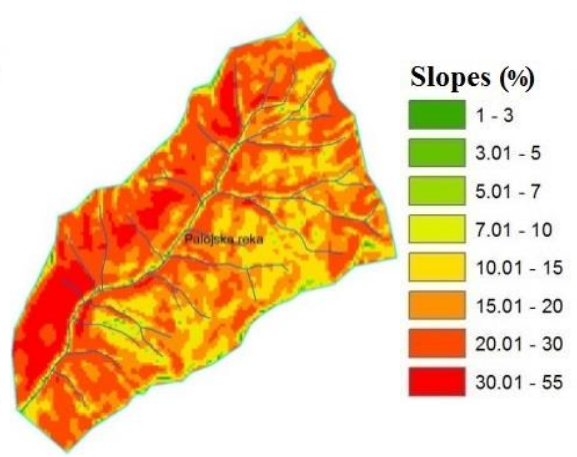

Picture 3. Slopes in the basin 
The bedrock consists mainly of metamorphic rocks, with a smaller share of sedimentary rocks. The rocks of the Vlasina complex, which originate from the Rifeya-Cambrian Epoch, account for $95.27 \%$ of the basin area. These are muscovite-chlorite schists, chlorite-muscovite schists, albite-chlorite-muscovite schists, and albite gneiss with chlorite (Braunović and Ratknić, 2012). These rocks are characterized by processes of intensive surface disintegration, which is proportional to the degree of slope. According to the resistance of rocks to erosion, these rocks belong to the categories of conditionally erodible and very erodible rocks. The soil type of the Palojska River Basin is dystric cambisol (Braunović, 2013).

\subsection{Methods}

In order to quantify changes in the intensity of erosion, a model of erosion potential - EPM was applied (Gavrilović, 1972), as well as a comparative analysis of the state of erosion processes before and after erosion control works were conducted in the channel and basin. According to Ratknić and Braunović (2016), the effects of natural factors, land use changes and human factors on the changes in the intensity of erosion in the basin were estimated on the basis of field research data (mapping of land use and excessive and severe erosion processes) for the period 2011-2012 and in 2016. Thematic maps (topographic, geological, pedological, land use and erosion maps) were also used. In order to process natural characteristics of the study area, we used a 1:50,000 topographic map (Vlasotince 1 sheet), geological map of Serbia 1:100,000 (Vlasotince sheet), and a pedological map of Grdelica Gorge and Vranje Valley 1:50,000 (1960). Climate characteristics of the area were based on data from 10 meteorological stations (Meteorological Yearbooks, 1961-2015). The types of bedrock can be grouped according to their resistance to erosion destruction in 4 categories (very solid, conditionally solid, conditionally erodible and very erodible rocks). The land use before the erosion control works was reconstructed on the basis of the existing documentation (Main design for the regulation of the Palojska River Basin, 1956; The Register of torrents of the right and left tributaries of the South Morava River on the GrdelicaVladičin Han section, 1964). The land use after the erosion control works was defined using homogeneous units, within which productive and non-productive areas were distinguished (Braunović et al., 2015). The state of erosion prior to the execution of erosion control works was determined on the basis of the erosion map of Grdelica Gorge and Vranje Valley (1956).

\section{RESULTS AND DISCUSSION}

\subsection{Land use}

According to data from 1953, forests (predominantly locust forests and occasionally oak, Turkey oak and Hungarian oak forests) accounted for $1 / 3$ of the basin area and they were characterized by poor protective function. The largest share was in ploughland and barrens $(40 \%)$, which directly affected the intensity of erosion processes (Braunović and Ratknić, 2010). Smaller areas were occupied by 
orchards, meadows and pastures, which were affected by processes of excessive and severe erosion.

Table 1. Types of land use before and after the execution of EC works

\begin{tabular}{|c|c|c|c|c|}
\hline \multirow[b]{2}{*}{ Land use categories } & \multicolumn{2}{|r|}{1953} & \multicolumn{2}{|r|}{2016} \\
\hline & $\begin{array}{c}\text { Area } \\
\text { (ha) }\end{array}$ & $\begin{array}{l}\text { Share in the } \\
\text { total area }(\%)\end{array}$ & $\begin{array}{c}\text { Area } \\
\text { (ha) }\end{array}$ & $\begin{array}{l}\text { Share in the } \\
\text { total area }(\%)\end{array}$ \\
\hline Barren land & 89.22 & 12.99 & - & - \\
\hline Forests & 245.15 & 35.68 & 474.55 & 69.07 \\
\hline Ploughland & 188.78 & 27.48 & 13.10 & 1.90 \\
\hline Meadows and pastures & 92.93 & 13.53 & 100.72 & 14.66 \\
\hline Degraded meadows and pastures & - & - & 26.3 & 3.83 \\
\hline Orchards & 70.92 & 10.32 & - & - \\
\hline Human settlements, road network, water courses & - & - & 72.33 & 10.54 \\
\hline - & 687 & 100.00 & 687 & 100.00 \\
\hline
\end{tabular}

In the period after the erosion control works, the share of forest areas increased by $33.4 \%$, and in 2016 it accounted for $69.07 \%$ of the basin area. The share of ploughland decreased by $25.58 \%$, while the share of meadows and pastures decreased slightly (Table 1).

\subsection{Socio-demographic characteristics}

According to the 2011 Census, there were about 132 households with 500 inhabitants living in the basin. The average household size was 3.43 members (Table 2). This catchment area was characterized by a decrease in the number of inhabitants in the period from 1981 to the present. The average age of the population increased from 29.3 years in 1971 to 41 years in 2011 (Comparative Population Survey, 2014).

Table 2. Changes in the number of inhabitants and households, household size

\begin{tabular}{|c|c|c|c|c|c|c|c|}
\hline \multicolumn{1}{|c|}{ and population density } \\
\cline { 2 - 8 } & \multicolumn{7}{|c|}{ Census year } \\
\cline { 2 - 8 } & 1953 & 1961 & 1971 & 1981 & 1991 & 2002 & 2011 \\
\cline { 2 - 8 } & \multicolumn{7}{|c|}{ Population } \\
\cline { 2 - 8 } CM & 475 & 458 & 446 & 526 & 512 & 484 & 453 \\
\cline { 2 - 8 } & \multicolumn{7}{|c|}{ Number of households } \\
\cline { 2 - 8 } & 77 & 94 & 101 & 125 & 123 & 142 & 132 \\
\cline { 2 - 8 } & \multicolumn{7}{|c|}{ Average household size } \\
\cline { 2 - 8 } & 6.17 & 4.87 & 4.42 & 4.21 & 4.16 & 3.41 & 3.43 \\
\cline { 2 - 8 } & \multicolumn{7}{|c|}{ Population density in the basin } \\
\cline { 2 - 7 } & 69.14 & 66.67 & 64.92 & 76.56 & 74.53 & 70.45 & 65.94 \\
\hline
\end{tabular}

The number of households increased in the period from 1953 to 1981, and the household size declined in all subsequent censuses. The basin had the highest population density in 1953, but it subesequently declined until 1971. In 1981, its rapid increase was recorded, followed by a constant decrease (Table 2). 


\subsection{Erosion control works performed in the basin}

In the period from 1947 to 1977, technical works in the basin of the Palojska River included $0.45 \mathrm{~km}$ of regulation and 12 dams and cascades (Jelić, 1978).

Table 3. Overview of erosion control works performed in the Palojska River Basin

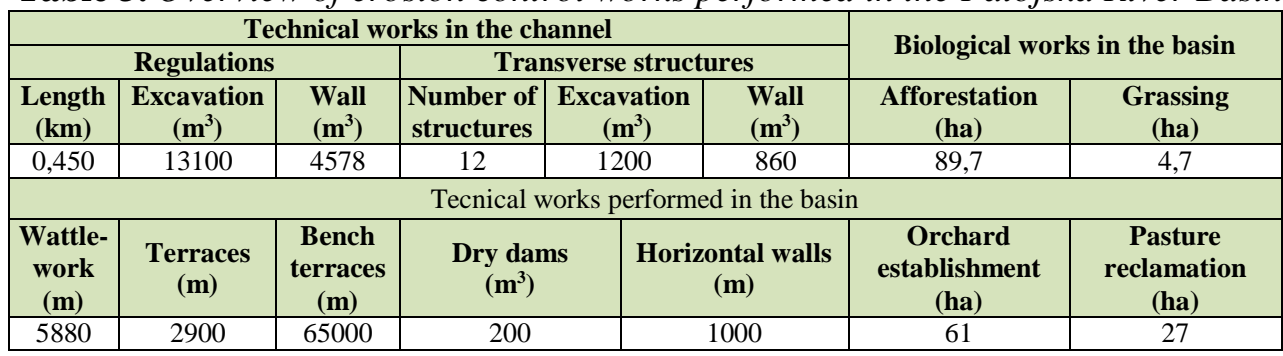

Biological works in the basin included afforestation, orchard establishment on terraces, pasture reclamation and grassing of eroded areas, all on 182.4 ha (27\% of the surface area of the basin) (Table 3). Austrian pine plantations were established on bench terraces and terraces. Wattle-work was constructed, as well as horizontal walls and dry dams. Finally, 3 ha were planted with poplar trees.

\subsection{Erosion Processes}

The mean coefficient of erosion in 1953 (i.e., before the erosion control works) was $Z_{\text {mean }}=1.02$, which means that the basin was affected by excessive erosion processes. The processes of severe erosion endangered half of the basin, the processes of excessive erosion $45.91 \%$ and moderate erosion $4.66 \%$ of the total area of the basin (Picture 4).

The mean coefficient of erosion for 2016 was $Z=0.28$ (weak erosion). The part of the basin area affected by weak erosion processes was $3.30 \mathrm{~km}^{2}(48.03 \%$ of the basin area), by very weak erosion $3,09 \mathrm{~km}^{2}$ (44.98\% of the basin area) and by moderate erosion $0.18 \mathrm{~km}^{2}$ (2.62\% of the basin area). Buildings, settlements, watercourses and road networks accounted for an area of $0.1 \mathrm{~km}^{2}$ (Picture 4).

Table 4. Sediment yield and transport in the Palojska River Basin

\begin{tabular}{|c|c|c|c|c|c|}
\hline \multirow{3}{*}{ Year } & \multicolumn{2}{|c|}{ Sediment yield } & \multirow{3}{*}{$\begin{array}{c}\text { Coefficient of } \\
\text { retention } \\
\text { Ru }\end{array}$} & \multicolumn{2}{|c|}{ Sediment transport } \\
\hline & specific & total & & specific & total \\
\hline & $\begin{array}{c}\text { Wsp } \\
\mathbf{m}^{3} \mathbf{k m}^{-2} \text { god }^{-1}\end{array}$ & $\begin{array}{c}\begin{array}{c}\text { Wyear } \\
\text { m }^{3} \text { year }^{-1}\end{array} \\
\end{array}$ & & $\begin{array}{c}\text { Gsp } \\
\mathrm{m}^{3} \mathrm{~km}^{-2} \text { year }^{-1}\end{array}$ & $\begin{array}{c}\text { Gyear } \\
\text { m }^{3} \text { year }^{-1}\end{array}$ \\
\hline 1953 & 2763.86 & \begin{tabular}{|l|}
18987.70 \\
\end{tabular} & \multirow[b]{2}{*}{0.24} & 663.33 & 4557.05 \\
\hline 2016 & 295.94 & \begin{tabular}{|l|}
2033.12 \\
\end{tabular} & & 71.03 & 487.95 \\
\hline
\end{tabular}

The total amount of sediment yielded in the basin (for the study periods) is shown in Table 4. The values of the mean erosion coefficient and the amount of sediment yielded and transported in the basin for both reference periods show that the processes of erosion have been calming down in the Palojska River Basin. 


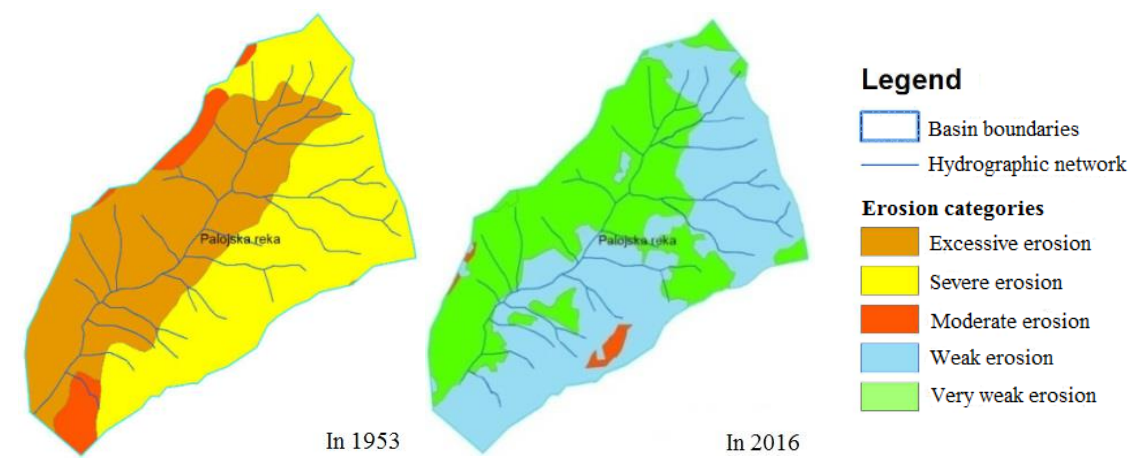

Picture 4. The map of erosion before and after the erosion control works

\section{CONCLUSION}

The reducing intensity of erosion process and declining total sediment yield (by $16954.58 \mathrm{~m}^{3} \mathrm{god}^{-1}$ ), along with the increasing forest cover (by 33.4\%) and reducing flood risk in the basin in the last 65 years have been the result of the erosion control works and active struggle against erosion. Furthermore, the reduction in the intensity of erosion was affected by the changes in sociodemographic factors, which were reflected on the changes in land use.

The control of erosion processes achieved through the application of adopted laws and decisions at the level of local self-government units is a prerequisite for unhindered traffic and effective protection of existing and future reservoirs, agricultural areas and settlements in Grdelica Gorge. However, besides the obvious effects of the works carried out in this area, the problems associated with investments and regular maintenance of the constructed objects are still evident.

\section{LITERATURE}

Braunović, S., Ratknić M., (2010): The Changes Of Land Use in Grdelicka Gorge and Vranjska Valley. International Scientific Conference 'Forest Ecosystems and Climate Changes`. Institute of Forestry, Belgrade. Proceedings, 83-88

Braunović, S., Ratknić, M. (2012): Impact of the Parent Rock on Erosion Process Development in Grdelica Gorge and Vranjska Valley. Sustainable Forestry, 65-66: 65-72

Braunović, S. (2013): Effects of erosion control works on the state of erosion in Grdelica Gorge and Vranje Valley. PhD Thesis, Faculty of Forestry, Belgrade (In original: Braunović, S. (2013): Efekti protiverozionih radova na stanje erozije u Grdeličkoj klisuri i Vranjskoj kotlini. Doktorska disertacija, Šumarski fakultet, Beograd)

Braunović, S., Ratknić, M., Ratknić, T., Kabiljo, M. (2015): Changes in Land Use in the Region of Grdelica Gorge in the period 1963-2011. Sustainable Forestry, 71-72: 77-84

Braunović, S., Ratknić, M., Rakonjac, Lj. (2017): The Role of Forest Ecosystems in the Risk Management of Torrential Floods (The Grdelica Gorge). VIII International Scientific 
Agricultural Symposium `Agrosym 2017`, Jahorina, University of East Sarajevo, Faculty of Agriculture, Bosnia and Herzegovina. Book of proceedings, 1860-1865

Braunović, S., Perović, V. (2017): Soil Erosion, Changes of Land Use and Migration Trends - Impact on Tourism Development. Tourism in Function of Development of the Republic of Serbia - Tourism Product as a Factor of Competitiveness of the Serbian Economy and Experiences of Other Countries, University of Kragujevac, Faculty of Hotel Management and Tourism, Vrnjačka Banja. Thematic proceedings II, 306-323

(2014): Comparative overview of the population 1948, 1953, 1961, 1971, 1981, 1991, 2002 and 2011(Book 20), Republic Institute of Statistics, Belgrade (In original: (2014): Uporedni pregled broja stanovnika 1948, 1953, 1961, 1971, 1981, 1991, 2002. i 2011. god. (Knj. 20), Republički zavod za statistiku, Beograd)

Gavrilović, S. (1972): Engineering of torrential flows and erosion. 'Izgradnja' Journal, Belgrade (In original: Gavrilović, S. (1972): Inženjering o bujičnim tokovima i eroziji. Izgradnja, Beograd)

Jelić, B. (1978): Erosion control works carried out in the Great Morava River Basin in the period 1947-1977. 'Erozija` Journal, 9: 25-42 (In original: Jelić, B. (1978): Protiverozioni radovi izvedeni u slivu Velike Morave u periodu 1947-1977. Erozija, 9: 25-42)

Kostadinov, S., Dragovic, N., Zlatic, M. and Todosijevic, M. (2008): Erosion Control Works and the Intensity of Soil Erosion in the Upper Part of the River Toplica Watershed. IOP Conf. Series: Earth and Environment Science 4, 012040, DOI: 10.1088/1755$1307 / 4 / 1 / 012040$

(1956): Main design for the regulation of the Palojska River Basin. Institute of Forestry, Belgrade (In original: (1956): Glavni projekat za uređenje sliva Palojska reka. Institut za šumarstvo, Beograd)

(1956): Map of the erosion of the area of Grdelica Gorge and Vranje Valley 1:50,000. Institute of pedology and agrochemistry, Belgrade (In original: (1956): Karta erozije područja Grdeličke klisure i Vranjske kotline 1:50 000. Institut za pedologiju i agrohemiju, Beograd)

(1961-2015): Meteorological Yearbooks. The Republic Hydrometeorological Service, Belgrade (In original: (1961-2015): Meteorološki godišnjaci. Republički hidrometeorološki zavod, Beograd)

(1960): Pedological map of the area of Grdelica Gorge and Vranje Valley 1:50,000. Institute of Pedology and Agrochemistry, Belgrade (In original: (1960): Pedološka karta područja Grdeličke klisure i Vranjske kotline 1:50 000. Institut za pedologiju i agrohemiju, Beograd)

(1964): Register of torrential catchments and slopes - Register of torrents of the right and left tributaries of the South Morava River on the Grdelica-Vladicin Han section, Grdelica Gorge. Regional section for the protection of soil from erosion and torrential flooding, Vladičin Han (In original: (1964): Registar bujičnih slivova i padina - Popis bujica desnih $i$ levih pritoka Južne Morave na deonici Grdelica-Vladičin Han, Grdelička klisura. Reonska sekcija za zaštitu zemljišta od erozije i uređenje bujica, Vladičin Han) 
Ratknić, M., Braunović, S. (2016): Study of the state and characteristics of regional erosion by the water of forest and agricultural land, causes, consequences and erosion control measures. Institute of Forestry, Belgrade. 1-624 (In original: Ratknić, M., Braunović, S. (2016): Studija Stanje $i$ odlike regionalne erozije vodom šumskog $i$ poljoprivrednog zemljišta, uzroci, posledice $i$ antierozione mere. Institut za šumarstvo, Beograd. 1-624) (http: //www.forest.org.rs/files/studija.pdf)

\title{
EFFECTS OF EROSION CONTROL WORKS IN THE DRAINAGE BASIN OF THE PALOJSKA RIVER (GRDELICA GORGE)
}

\author{
Sonja BRAUNOVIĆ, Filip JOVANOVIĆ, Milan KABILJO, Natalija MOMIROVIĆ
}

\begin{abstract}
Summary
The Palojska River is a right tributary of the South Morava River. It is located in Grdelica Gorge (southeastern Serbia). The source of the river is at $700 \mathrm{~m}$ a.s.l., and its mouth is at $265 \mathrm{~m}$ a.s.l., which points to its pronounced energy of relief. The basin is elongated covering an area of $6.87 \mathrm{~km}^{2}$. It stretches in the northeastern-southwestern direction, with its largest part (76.27\%) located in the altitudinal zone of 500-1000 m.

In order to quantify changes in the intensity of erosion, the EPM (model of erosion potential) was applied, as well as a comparative analysis of the state of erosion processes before and after the erosion control works were conducted in the channel and basin. Data were obtained from field investigations (2011-2012; 2016), thematic maps (topographic, geological, pedological, land use and erosion maps) and satellite images.

In the period from 1947 to 1977, technical works in the basin of the Palojska River included $0.45 \mathrm{~km}$ of regulation and 12 transverse structures. Biological works were carried out on $27 \%$ of the basin area (afforestation, orchard establishment on terraces, pasture reclamation and grassing of eroded areas). Austrian pine plantations were built on bench terraces and terraces, along with wattle-work, horizontal walls and dry dams, while 3 ha were planted with poplar trees. Biological and technical works performed in the basin increased the forest cover by $33.4 \%$, and the intensity of erosion processes in the study period decreased from surface excessive erosion $(Z=1.02)$ in 1953 to mixed weak erosion $(\mathrm{Z}=0.28)$ in 2016 , with a decrease in the sediment yield and transport in the basin. The effects of socio-demographic changes (a decrease in the number of inhabitants and an increase in the average population age) are reflected in the abandonment of agricultural land in the upper parts of the basin.

The reducing intensity of erosion processes and declining total sediment yield and transport (by $16954.58 \mathrm{~m}^{3} \mathrm{year}^{-1}$ ), along with the increasing forest cover in the basin (33.4\%) and reducing flood risk in the study period are the result of the erosion control works performed in the basin and partly of the changes in sociodemography. However, besides the obvious effects of the works carried out in this area, the problems associated with the investments and regular maintenance of the constructed objects are still evident.
\end{abstract}




\title{
EFEKTI PROTIVEROZIONIH RADOVA U SLIVU PALOJSKE REKE (GRDELIČKA KLISURA)
}

\author{
Sonja BRAUNOVIĆ, Filip JOVANOVIĆ, Milan KABILJO, Natalija MOMIROVIĆ
}

\section{Rezime}

Palojska reka je desna pritoka Južne Morave i nalazi se u Grdeličkoj klisuri (jugoistočna Srbija). Izvorište ove reke je na 700 m n.v., a ušće joj je na 265 m n.v., što govori o izraženosti energije reljefa. Sliv je izduženog oblika i prostire se na površini 6,87 $\mathrm{km}^{2} \mathrm{u}$ pravcu severoistok-jugozapad, pri čemu se njegov najveći deo $(76,27 \%)$ nalazi u visinskoj zoni 500-1000 m n.v.

Za kvantifikaciju promena intenziteta erozije primenjen je EPM (model potencijala erozije) i komparativna analiza stanja erozionih procesa pre i posle izvođenja protiverozionih radova. Izvor podataka bila su terenska istraživanja (2011-2012; 2016), tematske karte (topografska, geološka, pedološka, karta načina korišćenja zemljišta i karte erozije) i satelitski snimak.

Između 1947. i 1977. god. u slivu Palojske reke izvedeno je 0,45 km regulacije korita, uz 12 poprečnih objekata. Biološki radovi su obuhvatili $27 \%$ površine sliva (pošumljavanje, podizanje voćnjaka na terasama, melioracija pašnjaka i zatravljivanje erodiranih površina). Podignute su kulture crnog bora na gradonima i terasama, uz izradu pletera, kao i vodoravnih zidova i rustikalnih pregrada, dok je 3 ha pošumljeno topolom. Kao rezultat izvedenih bioloških i tehničkih radova, učešće površina pod šumom povećalo se za 33,4\%, a intenzitet erozionih procesa u posmatranom periodu smanjio se od površinske ekscesivne erozije $(Z=1,02)$ u 1953. god. do mešovite slabe erozije $(Z=0,28)$ u 2016. god., uz smanjenje produkcije i pronosa nanosa u slivu. Posledice sociodemografskih promena (smanjenje broja stanovnika i povećanje prosečne starosti stanovništva) izražavaju se kroz napuštanje poljoprivrednih površina u višim delovima sliva.

Smanjenje intenziteta procesa erozije i ukupne produkcije nanosa (za 16954,58 $\left.\mathrm{m}^{3} \operatorname{god}^{-1}\right)$, povećanje pošumljenosti sliva $(33,4 \%)$ i smanjenje rizika od poplava u istraživanom periodu, rezultat su izvedenih protiverozionih radova, a delom i promena sociodemografskog faktora. Međutim, i pored značaja efekata ovih radova na datom slivnom području, problem investicija i redovnog održavanja izgrađenih objekata i dalje je izražen. 